Article

\title{
Green and Reverse Logistics in Conditions of Sustainable Development in Enterprises in Slovakia
}

\author{
Patrik Richnák*(D) and Klaudia Gubová \\ Department of Production Management and Logistics, Faculty of Business Management, University of \\ Economics in Bratislava, 85235 Bratislava, Slovakia; klaudia.gubova@euba.sk \\ * Correspondence: patrik.richnak@euba.sk; Tel.: +421-2-6729-5528
}

Citation: Richnák, P.; Gubová, K.

Green and Reverse Logistics in Conditions of Sustainable Development in Enterprises in

Slovakia. Sustainability 2021, 13, 581. https://doi.org/10.3390/su13020581

Received: 14 December 2020

Accepted: 6 January 2021

Published: 9 January 2021
Publisher's Note: MDPI stays neutral with regard to jurisdictional clai$\mathrm{ms}$ in published maps and institutional affiliations.

Copyright: $\odot 2021$ by the authors. Licensee MDPI, Basel, Switzerland. This article is an open access article distributed under the terms and conditions of the Creative Commons Attribution (CC BY) license (https:// creativecommons.org/licenses/by/ $4.0 /)$.

\begin{abstract}
The high quality of the environment, protection of natural resources, efficient use of natural resources, and elimination of environmental burdens are the main priorities of sustainable development. Therefore, enterprises around the world have to manage the environment wisely, while avoiding negative effects on it. The aim of the paper was to examine the use of green and reverse logistics in the conditions of sustainable development in enterprises in Slovakia. The intention of the paper was to provide a theoretical overview of green and reverse logistics at home and abroad on the basis of the elaboration of a scientific bibliographic-information apparatus. Subsequent practical implementation of the questionnaire research and statistical verification of research results provides a basis for practical recommendations and conclusions for enterprises operating in Slovakia. The research topic of the paper was green and reverse logistics in companies in Slovakia. The research problem was the implementation and use of modern logistics under the influence of the environment. Based on these facts, statistical hypotheses were determined and subsequently tested. Descriptive statistics and inference statistics were used to interpret the research results. Based on the research, we found that the dominant position in green and reverse logistics in Slovakia was achieved by large production enterprises from the automotive industry, which operate in western Slovakia. The analysed enterprises in Slovakia use voluntary tools of environmental policy and the most important environmental tool is corporate social responsibility. Elements of environmental policy are used primarily in the logistics process of warehousing and storage. The biggest barrier in the implementation of elements of environmental logistics analysed by enterprises is the lack of financial resources. The implementation of green logistics and reverse logistics enables the analysed enterprises in Slovakia to improve customer-supplier relations. We can say that despite the government's efforts, measures to minimize the environmental impact and growing public awareness of environmental issues, environmental problems persist. Initiatives can be seen at the global and national levels of enterprises that make quick decisions and set up new processes in environmental management.
\end{abstract}

Keywords: green logistics; reverse logistics; sustainable development

\section{Introduction}

Sustainability is an often inflected term at home and abroad. Currently, there is significant environmental pollution worldwide, which increases the emphasis on the sustainability of enterprises. The response and solution to the situation is to plan and set political, social and technological priorities in order to ensure a sustainable supply chain. Green and sustainable products are subject to high consumer demand and are increasingly required by government regulation. Under the growing environmental considerations, many countries have implemented environmental protection laws to reduce the environmental impact of industry [1]. According Maciková et al. [2] sustainability is a central factor limiting business behavior and awareness of the issue is sensitively perceived especially during an economic crisis when businesses are undertaking an extensive restructuring of their businesses and are looking for new fields of action. 
With the growing global dependence of enterprises, their responsibility for environmental, social and human rights related to their activities is gradually growing. In this context, enterprises are increasingly responsible for the social and environmental problems that fall within the sphere of operation of their suppliers and subcontractors within the logistics chain. Public administration and government policy should support both entrepreneurship and innovation, as such support is essential for organizations in developing policies for growth and sustainability [3]. Not only businesses but also customers are aware of the importance of the environment. They must respect stricter environmental regulations that affect the entire supply chain [4]. Constantly growing globalization and industrialization place significant demands on ecological and sustainable logistics. Currently, the focus is mainly on reducing negative externalities in the preparation of and improving the performance of the supply chain [5]. Sustainable logistics can be defined as the analysis and support of sustainable procurement, sustainable transport, sustainable packaging, sustainable distribution, reverse logistics, and design and control of sustainable supply chain activities [6]. Trivellas et al. [7] believe that logistics functions are interdependent and compromises are required in all areas of sustainability. An example of dependency is a reusable packaging system that increases resource efficiency, leading to cost savings, but also produces more reverse logistics routes and consequently higher emissions in transport. The aim of sustainable logistics is to provide basic arguments to persuade decision-makers to approve initiatives in logistics with respect for the environment [8]. To ensure environmentally sustainable logistics, organizations need to have an environmentally sustainable logistics performance management process [9]. Kaur and Singh [10] draw attention in the context of sustainable logistics to the carbon emissions that arise from the purchase of raw materials to the distribution of finished products. The authors emphasize the need to create an environmentally sustainable supply chain.

Many enterprises are currently promoting the concept of green or environmental innovation. However, relatively little research attention has been paid to considering the relationships between green product innovation, business performance and competitiveness. In their study, Shaofei et al. [11] discuss the relationship between additional services for products and the sustainability of innovation, where they found a significant relationship between them. Manufacturers take sustainability into consideration with an emphasis on resources. Entrepreneurship and innovation are considered to be mechanisms for achieving the goals of sustainable development, but the literature has paid less attention to sustainable development within entrepreneurship [12,13].

With the rapid growth of the global economy, there is scope for questions about resources and their relationship to the environment, which are becoming a key obstacle to sustainable economic development. How to alleviate the conflicts between economic growth and high energy consumption, as well as environmental degradation, is a challenge for the European Union (EU) and the world [14]. The sustainability transitions literature thus focuses on multidimensional transformation processes (technological, institutional, political, economic) to promote more sustainable production and consumption [15]. Gartner [16] found in his survey that $30 \%$ of respondents have no sustainability or low maturity initiatives, which means that they either do not have a formal sustainability agenda today.

The aim of the development of new technologies and innovations in logistics are expectations that will bring a positive result in the field of sustainability and preservation of the quality of the environment worldwide. These benefits include saving energy, reducing emissions, improving recycling, reducing environmental pollution. According to Carrion-Flores and Innes [17], it can also reduce waste and environmental damage to the planet, provide better goods and services at a lower cost, and create jobs for people. In contrast, Garrette et al. [18] argue that sustainable innovation and design are not necessarily related to new technologies but to the rethinking of approaches to address the need for growth while reducing negative environmental and social impacts. In general, innovation can be considered a key factor in the sustainability of enterprises. No matter what kind of innovation it is. Sustainability concerns both product and process innovations. Also if we 
talk about technological, social, environmental innovations. Green product innovation has formed as a result of the interaction between sustainability and innovation [19]. If an enterprise wants to apply the principles of sustainability, it is necessary that the individual steps be included in different areas of business activity. According to Frenken and Faber [20], environmental innovation provides an important key to sustainability. Rave et al. [21] argue that green innovation facilities play a key role in the company's environmental performance results and comprehensive environmental sustainability realization. Pacheco et al. [22] argue that green institutions should be set up by municipal institutions to improve the competitiveness of sustainable behavior. Muñoz-Pascual et al. [23] in their study used a mixed methods approach to identify the antecedents of the adoption of environmental practices and sustainable product innovation performance in context. Furthermore, sustainable development requires a society pool approach to innovation whereby different stakeholders (e.g., trade partners, employees, governments for innovation's projects) are involved. In addition, their research questions examine differences in innovation performance between small and medium enterprises (SMEs) with different legal forms. SMEs with different legal forms can have different sustainability aims. Elements of sustainability can be seen in various areas of enterprises. One is also the construction industry, where it constantly offers new products, more effective technologies and novel solutions aimed at improving the quality of human habitats and wider distribution of technologies. Currently, effective technologies that require less time and cost for production, installation and use are gaining greater significance. Among them are construction materials and technologies with increasingly popular sustainability features [24].

Emphasis is also placed on sustainable development in logistics, if we talk about green and reverse logistics by linking to supply chain management. The development of transport and logistics plays a crucial role in the industrial sectors and activities of the countries' economies. Economic development requires a well-functioning transport system [25]. Freight transport currently faces a number of challenges, especially in the environmental and social field, by leading to various forms of air, water and soil pollution and noise, and contributing to global warming. Lowering the total traveled kilometers brings extra environmental benefits in the form of reduced number of vehicles on the roads. This will in turn lead to reduced congestion, fewer accidents and less traffic. This is why the logistics community is turning to green logistics as a crucial concept for a sustainable logistics operation. Seroka-Stolka and Ociepa-Kubicka [26] say that green logistics is a development trend of modern logistics. Green logistics is the main element and basic system of development of the circular economy. The circular economy represents a means as the realization of a closed loop of material flows in the economic system. Green logistics is a concept that connects resources and products, products and consumers. Jastrzebska [27] says that the circular economy relies on closing cycles of extended product life. The author also says that waste is a valuable recycled material. Green and sustainable logistics represents the planning, control, management and implementation of a logistics system using advanced logistics technologies and environmental management [28]. The main aim of green logistics is to eliminate environmental damage caused by logistics activities. Green logistics aims to strike a sustainable balance between economic, social and environmental aims [29]. In green logistics, Huang et al. [30] draws attention to the direct relationship between efficiency and cooperation. Cooperation can reduce logistics costs and the negative impact of the bullwhip effect and increase service levels. Assessing the degree of synergy is key to analysing cooperation, identifying weaknesses, supporting development and is also a key step in building a green logistics system. Polychroniou et al. [31] consider green logistics innovation packaging. This logistics process has a direct impact on the environment. The main task of sustainable packaging design is to balance the sustainability function with the critical packaging functions. Ni et al. [32] say that green logistics aims to reduce environmental pollution by agricultural products. Systematic implementation of green logistics methods and tools will ensure the achievement of sustainable development aims [33]. Helo and Ala-Harja [34] combine green logistics with greenhouse gas emissions. 
These have been introduced into supply chain management as an additional parameter to traditional key performance indicators such as costs, delivery times and on-time deliveries. An important approach to green logistics is the use of alternative energy sources, the attempt to deploy or use alternative fuels to completely or partially replace the use of fossil fuels [35].

We are currently witnessing the introduction and implementation of sustainable development in production enterprises through the concept of a green supply chain. Green regulations, principles and innovative practices for suppliers and enterprises have attracted the interest of managers and practitioners. The emergence of Green Supply Chain Management has brought the concept of eco-efficiency within the supply chain involving more effective environmental issues throughout the production chain [36]. Combining green logistics with digitalisation will achieve sustainability, with a number of benefits such as reducing the carbon footprint, efficient optimization of transport routes, reduction of transport time and costs, waste minimization, reduction and better optimization of logistics networks. Digital logistics is the most efficient and at the same time least risky way of implementing elements of sustainability into supply chain management. By applying elements of sustainability to SCM, sustainable supply chain management is created, which supports efficiency and in the long run it becomes a factor in ensuring the profitability of logistics enterprises. Cherrafi et al. [37] talks about the green supply chain. The authors revealed a synergistic effect between process innovations, green and lean practices, which play a crucial role in improving the performance of the green supply chain. The research carried out by the authors found that the performance of the logistics chain is influenced by eco-design, life cycle assessment, ecological production, reverse logistics and waste management. Dubey et al. [38]; Genovese et al. [39]; Govindan et al. [40] say that the green supply chain has the task of reaching a trade-off between profit and environmental sustainability. Author Gang [41] analyses the impact policy makers have on both energy saving levels and the prices set by green supply chains when they set the threshold value of energy saving levels. Then, from the perspective of the policy maker, the trade off between energy savings and the profits of green supply chains is analysed. Green supply chain management is a concept that is gaining popularity all over the world. Moreover, it is a way to demonstrate commitment to sustainability and to be fully adopted by the organizations it should contribute to better economic performances and competitiveness. Recently there have been many incentives for more sustainable warehousing in supply chains [42]. Lee et al. [43] emphasize the importance of support from large buying firms for improving SME suppliers' green management capabilities. It was also found that implementation of green supply chain management (GSCM) practices help improve operational and relational efficiencies of supplier enterprises. The manufacturing firms should implement environmentally sound practices in all phases of the supply chain, beginning with the procurement of raw materials and supplies through to design, manufacture, packaging, distribution of their products and end of life disposal. In doing so, they are likely to perform better financially and marketwise [44]. The results of the study and previous studies by Eltayeb et al. [45], imply that externally-oriented green supply chain initiatives, such as green purchasing and reverse logistics, have little effect on the internal performance of the firm. This may indicate that the benefits of these initiatives may reflect on external parties rather than on the firm. For instance, in green purchasing the firm focuses on improving environmental performance of its suppliers. While the benefit of such an initiative may reflect indirectly on the firm, through obtaining green materials and other inputs, the direct effect goes to suppliers. Authors study Mitra and Datta [46] deal with research on GSCM or sustainable supply chain management (SSCM) has attracted increased attention in recent years. Results of data analysis showed that supplier collaboration for environmental sustainability had a positive impact on environmentally sustainable product design and logistics, which in turn was positively related to competitiveness and economic performance of the enterprise. 
The core of reverse logistics is derived from environmental issues. Currently, population grows, which means increased product demand increasing requirements on natural resources leading to growing waste. Wasteland capacity and natural resources are exhaustible which invokes the need to think about new possibilities of repeatable use and disposal of industrial waste [47]. Reverse logistics is disciplined in a legal diploma officially called the Solid Waste Act. The law reinforces the management criteria, indicating that the generator has responsibilities over the waste generated and for the final disposal of their product or service. The private sector should be invited to participate with investments in recycling plants [48]. Reverse logistics is gaining increasing attention. It is a means by which products are treated ecologically during their lifetime $[49,50]$. Reverse logistics focuses primarily on the return or take-back products and materials from the point of consumption to the forward supply chain for the purpose of recycling, reuse, remanufacture, repair, refurbishing, or safe disposal of the products and materials [51]. Reverse logistics flow is an unprecedented tool that works for the development of company activities through economic, operational and environmental practices [52]. Reverse logistics practices are not effective if it cannot reduce transportation expenses and bounded with uncertainty [53]. Reverse logistics encompasses the traditional logistics activities of transportation and inventory management, but its focus is to get a product back from customers rather than moving a product to customers [54]. Sustainable logistics practices help manage changes that save costs, strengthen market positions and generate additional revenue streams. The reverse logistics strategy is to carry out activities related to the reuse of materials and products [55]. Ya-Ping [56] focused specifically on cost and benefit analysis considering reverse logistics as an important element of an enterprise. The review on cost analysis of reverse logistics refers to the material consumption in monetary terms to regain the value during the process. He has further provided cost components, such as collection costs, disassembly costs, testing and classification costs, environmental protection costs and disposition costs that may exist in reverse logistics. Doan et al. [57] talks about the reverse supply chain in connection with electronic waste.

Globalization aims at sustainability, but without the development of technology, globalization would not be sustainable. In order to establish and manage the sustainability of enterprises, it is essential to share in social responsibility, protect natural resources and preserve the quality of the environment. The issue of green and reverse logistics has an irreplaceable place worldwide. The proof is a comparative view of the authors opinions in the previous paragraphs of the article. We can state that despite government efforts, measures to minimize the environmental impact and growing public awareness of environmental issues, environmental problems persist. Initiatives can be seen at the global and national levels of enterprises that make prompt decisions and set up new environmental management processes.

\section{Materials and Methods}

The aim of the paper was to examine the use of green and reverse logistics in the conditions of sustainable development in enterprises in Slovakia. The intention of the paper was to provide a theoretical overview of green and reverse logistics at home and abroad on the basis of the elaboration of a scientific bibliographic-information apparatus. Subsequent practical implementation of the questionnaire research and statistical verification of research results provides a basis for practical recommendations and conclusions for enterprises operating in Slovakia. The high quality of environment, protection of natural resources, efficient use of natural resources, and elimination of environmental burdens are the priorities of sustainable development. Therefore, enterprises have to manage the environment wisely, while avoiding negative effects on the environment. Based on the aforementioned facts, enterprises can achieve a competitive advantage in the market.

The object of the research, which was carried out by a questionnaire, were small, medium-sized and large enterprises in Slovakia. The categorization of enterprises by size was based on the EU Commission Regulation No. 651/2014 (small enterprise: staff 
headcount: $<50$, turnover: $\leq € 10$ million, balance sheet total: $\leq € 10$ million; mediumsized enterprise: staff headcount: <250, turnover: $\leq € 50$ million, balance sheet total: $\leq € 43$ million; large enterprise: staff headcount: $>250$, turnover: $>€ 50$ million, balance sheet total: $>€ 43$ million).

The research tool was a questionnaire. It consisted of 25 questions and contained open-ended, closed-ended, semi-closed-ended and rating scale questions. The Likert scale was used to generate the rating scale questions. The questionnaire was developed in both electronic and written forms. The questionnaire was distributed using several data collection methods: computer-assisted web interviewing (CAWI), computer-assisted telephone interviewing (CATI) and computer-assisted personal interviewing (CAPI).

The elaboration of the paper required utilisation of both classical and specific scientific methods. As for the classical methods, the method of literature search, the method of analysis and synthesis, the method of induction and deduction, the method of comparison and the method of scientific abstraction were used. The specific methods used were: the methods of inquiry, the method of elimination, the method of sorting, the method of concretization and mathematical-statistical methods. One-dimensional and two-dimensional descriptive statistics were used to process the data from the questionnaire.

For statistical testing, we used Pearson's chi-square test $\left(\chi^{2}\right)$, test of goodness of fit. Based on a preselected level of significance $\alpha$, the tests of goodness of fit allow us to test the null hypothesis $\mathrm{H}_{0}$ versus the alternative hypothesis $\mathrm{H}_{1}$ [58]. Pearson's chi-squared test $\left(\chi^{2}\right)$ is a modification of Chi-squared $\left(\chi^{2}\right)$, test of goodness of fit, in which observed frequencies $\left(O_{i j}\right)$ are compared with expected frequencies $\left(E_{i j}\right)$. Comparison of observed and expected frequencies is a primary thought of the Chi-squared $\left(\chi^{2}\right)$, test of goodness of fit. The null hypothesis $\left(\mathrm{H}_{0}\right)$ - between categorical variables $\mathrm{A}$ and $\mathrm{B}$ there is no dependence (there is no contingency) against an alternative hypothesis $\left(\mathrm{H}_{1}\right)$ - between categorical variables $\mathrm{A}$ and $\mathrm{B}$ there is dependence (there is contingency), we verify with a test characteristic, which is called square contingency [59]:

$$
\chi^{2}=\sum_{j=1}^{s} \sum_{i=1}^{r} \frac{\left(O_{i j}-E_{i j}\right)^{2}}{E_{i j}}
$$

where: $s$-number of columns; $r$-number of rows; $O_{i j}$-observed frequencies, $E_{i j}$-expected frequencies

Under the assumption of validity of null analysis, square contingency has an asymptotic $\chi^{2}$-division with degree of freedom $((r-1) \cdot(s-1))$. Critical area is restricted by inequality $\chi^{2}>\chi^{2} 1-\alpha((r-1) \cdot(s-1))$.

Pearson's contingency coefficient, Tschuprow's contingency coefficient, and Cramer's contingency coefficient were used to assess intensity of contingency.

Pearson's contingency coefficient is calculated based on relationship [59]:

$$
C=\sqrt{\frac{\varnothing^{2}}{1+\varnothing^{2}}=\sqrt{\frac{\chi^{2}}{n+\chi^{2}}}}
$$

where: C-Pearson's contingency coefficient; $\varnothing^{2}$-mean square contingency; $\chi^{2}$ —the chi-square statistic; $\mathrm{n}$ - the total number of observations

Based on this relationship it is clear that for null value of square contingency (perfect agreement of observed and expected frequencies) Pearson's contingency coefficient takes the value 0 . If the value of contingency coefficient is close to the value 1 it signals increasing intensity of dependence between variables.

Tschuprow's contingency coefficient can be calculated based on relationship [59]:

$$
\tau=\sqrt{\frac{\varnothing^{2}}{\sqrt{(\mathrm{r}-1) \cdot(\mathrm{s}-1)}}}
$$


where: $\tau$-Tschuprow's contingency coefficient; $\varnothing^{2}$-mean square contingency; r-rows in the contingency table; $\mathrm{s}$-columns in the contingency table

If the contingency table is not square, it means $r \neq s$, then this coefficient will never reach the value 1 .

Cramer's contingency coefficient is calculated based on relationship [59]:

$$
\mathrm{V}=\sqrt{\frac{\chi^{2}}{\mathrm{n} \cdot \mathrm{h}}}
$$

where: $\chi^{2}$-the chi-square statistic; $\mathrm{n}$-the total number of observations; $\mathrm{h}-$ number of minimum row of column in the contingency table

If the Cramer's coefficient achieved values between 0 and 0.3 , then there is a weak dependence between variables. If it reached values between 0.3 and 0.8 , it indicates a medium contingency and values between 0.8 and 1 indicate a strong dependence of variables.

\section{Results}

Out of the total number of respondents (165) participating in the research, the highest percentage of enterprises $(46.1 \%$ ) were in the medium-sized category. The second largest group of enterprises $(42.4 \%)$ were large enterprises. The lowest percentage of enterprises $(11.5 \%)$ belonged to the small enterprise category.

The research was conducted in the Slovak Republic, which consists of eight regions. Out of the research sample, $27.3 \%$ of enterprises were from the Trnava Region. It was followed by the Bratislava Region with 23\%. The analysed enterprises in the Nitra Region occupied third place with a share of $14.5 \%$. The lowest number of enterprises involved in the research (3.6\%) were from the Prešov Region.

Out of the analysed enterprises, production enterprises were the most widely represented with a share of $81.2 \%$. The analysed enterprises providing services took a share of $12.7 \%$. Trade enterprises were represented in the research with the lowest share of $6.1 \%$.

The largest part of the analysed enterprises operated in the automotive industry with a share of $23.6 \%$. The engineering industry covered a share of $21.8 \%$ in the research sample, while the electrical engineering industry occupied a share of $17.2 \%$. The least involved analysed enterprises with the share of $3 \%$ were those from the chemical industry and glass industry $(1.2 \%)$.

Climate change in the form of global warming and the soil, water and air pollution significantly affects the environment. Environmental issues have become global, and sustainable development, which has stimulated the emergence of an environmental strategy for business development, has been integrated into businesses.

In the following part of the paper, the results of research dealing with green and reverse logistics in the conditions of sustainable development in enterprises will be evaluated and interpreted. Out of the analysed enterprises, large enterprises enforce the environmental policy most widely $(47.3 \%)$. The research sample promotes environmental policy with a share of $45.5 \%$ in medium-sized enterprises. The analysed enterprises enforce environmental policy with a share $7.2 \%$ in small enterprises. The respondents enforce environmental policy with a share of $76.4 \%$ in production enterprises. The research sample utilise environmental policy achieved a share of $16.4 \%$ in trade enterprises. The respondents enforce environmental policy with a share of $7.2 \%$ in enterprises providing services. The analysed enterprises in the automotive industry promote environmental policy with a share of $21.2 \%$. The respondents application of environmental policy with the lowest percentage $(1.2 \%)$ were in glass industry. The analysed enterprises in the Trnava Region achieved the highest percentage share $(22.8 \%)$ in the enforcement of environmental policy. The lowest degree $(4.1 \%)$ of the environmental policy implementation was identified in the analysed enterprises from the Prešov Region.

Authors show selected results in Table 1. The most frequently occurring value (mode) recorded was 4 . This value was achieved thanks the application of environmental policy in the automotive industry. Within production enterprises, the automotive industry in 
the Trnava Region was recorded the highest median value (2.5). The lowest value of standard deviation (1.398) was achieved in implementation of environmental policy in the automotive industry. The highest value of standard deviation (2.053) was obtained in application of environmental policy in the Prešov Region.

Table 1. Descriptive statistics.

\begin{tabular}{|c|c|c|c|c|c|c|}
\hline \multirow{2}{*}{ Promote Environmental Policy } & \multicolumn{2}{|c|}{ Frequency } & \multirow{2}{*}{ Mean } & \multirow{2}{*}{ Median } & \multirow{2}{*}{ Mode } & \multirow{2}{*}{ Std. Deviation } \\
\hline & Absolute & Relative & & & & \\
\hline Small enterprises & 12 & $7.2 \%$ & 3.00 & 1 & 0 & 2.000 \\
\hline Medium-sized enterprises & 75 & $45.5 \%$ & 3.19 & 2 & 2 & 1.791 \\
\hline Large enterprises & 78 & $47.3 \%$ & 3.36 & 2 & 2 & 1.454 \\
\hline Production enterprises & 126 & $76.4 \%$ & 3.91 & 2.5 & 2 & 1.601 \\
\hline Trade enterprises & 27 & $16.4 \%$ & 3.58 & 2 & 3 & 1.674 \\
\hline Service enterprises & 12 & $7.2 \%$ & 2.59 & 1 & 0 & 1.826 \\
\hline Automotive Industry & 35 & $21.2 \%$ & 4 & 2.5 & 4 & 1.398 \\
\hline Glass Industry & 2 & $1.2 \%$ & 2.38 & 1 & 1 & 1.995 \\
\hline Trnava Region & 38 & $22.8 \%$ & 4 & 2.5 & 3 & 1.537 \\
\hline Prešov Region & 7 & $4.1 \%$ & 2.75 & 1 & 1 & 2.053 \\
\hline
\end{tabular}

Source: own processing.

Out of the environmental policy instruments, analysed enterprises most frequently utilise voluntary instruments $(36.5 \%)$, which are followed by legislative instruments (32.8\%). Table 2 reveals the mean value, median value, mode value and standard deviations. The largest mean of 3.56 was achieved by the enterprises in Slovakia using voluntary instruments of environmental policy. The use of legislative instruments of environmental policy recorded the mean value of 2.67. Voluntary instruments of environmental policy achieved the highest modus value (3). Economic instruments and voluntary instruments of environmental policy reached the median value of 2.5. The values are significantly dispersed regarding the economic instruments of environmental policy; the standard deviation reached the value of 1.806. The lowest dispersion of values was recorded in terms of voluntary environmental instruments; the standard deviation reached the value of 1.318.

Table 2. Descriptive statistics.

\begin{tabular}{lccccccc}
\hline \multirow{2}{*}{$\begin{array}{c}\text { Environmental Policy } \\
\text { Instruments }\end{array}$} & \multicolumn{2}{c}{ Frequency } & \multirow{2}{*}{ Mean } & Median & Mode & Std. Deviation \\
\cline { 2 - 5 } & Absolute & Relative & & & & \\
\hline Economic instruments & 51 & $30.7 \%$ & 3.48 & 2.5 & 2 & 1.806 \\
Legislative instruments & 54 & $32.8 \%$ & 2.67 & 1 & 1 & 1.670 \\
Voluntary instruments & 60 & $36.5 \%$ & 3.56 & 2.5 & 3 & 1.318 \\
\hline Source: own processing. & & & & & &
\end{tabular}

Out of the selected voluntary instruments of environmental policy, corporate social responsibility was the most widely used in the analysed enterprises in Slovakia. The research sample uses corporate social responsibility with a share $29.8 \%$. A high share $(24.6 \%)$ of analysed enterprises use environmental management systems ISO 14001. The research sample uses eco-management and audit scheme (EMAS) with a share of 22.7\%. Environmental technologies of voluntary environmental policy instruments recorded the smallest percentage $(11.3 \%)$.

The principles of environmental policy also affect corporate logistics. Production logistics is the most significantly influenced by the environment. The research sample rated this option with share $37.7 \%$. The influence of environment in distribution logistics covered a share of $33.9 \%$. The lowest impact of environmental policy $(28.4 \%)$ was recorded in procurement logistics.

Authors provides descriptive statistics based on the respondents' replies in the Table 3. The highest value of the mean (2.88) was achieved by production logistics. The smallest 
value of the mean (1.94) was obtained by procurement logistics. Production logistics recorded the highest value (3) of the mode and also of the highest value (2.5) of the was. Procurement logistics reached the smallest value of mode value (1) and also the smallest value (0) of the median value. The highest value of the standard deviation (2.380) was obtained by procurement logistics. The lowest value of the standard deviation (1.342) was reached by distribution logistics.

Table 3. Descriptive statistics.

\begin{tabular}{|c|c|c|c|c|c|c|}
\hline & \multicolumn{2}{|c|}{ Frequency } & \multirow{2}{*}{ Mean } & \multirow{2}{*}{ Median } & \multirow{2}{*}{ Mode } & \multirow{2}{*}{ Std. Deviation } \\
\hline & Absolute & Relative & & & & \\
\hline Procurement logistics & 47 & $28.4 \%$ & 1.94 & 0 & 1 & 2.380 \\
\hline Production logistics & 62 & $37.7 \%$ & 2.88 & 2.5 & 3 & 2.088 \\
\hline Distribution logistics & 56 & $33.9 \%$ & 2.40 & 2 & 2 & 1.342 \\
\hline
\end{tabular}
Source: own processing.

The evaluated percentages suggest that warehousing and storage are the preferred elements of environmental policy in the logistics process in the analysed enterprises; the opinion achieved allotted a share of $30.3 \%$. A high percentage $(26 \%)$ was allotted to the logistics packaging process. The least popular element of environmental policy introduced by enterprises into logistics process was inventory management with $5.3 \%$.

Table 4 reveals the mean value, median value, mode value and standard deviation. The logistics process-warehousing and storage, obtained the largest mean value (2.68). The logistics process-inventory management, achieved the smallest mean value (1.14). The mode value achieved the highest value (2) in logistics processes-warehousing and storage and packaging. The median value obtained a value of 2 in logistics processeswarehousing and storage and packaging. The values are significantly dispersed regarding the logistics process-packaging; the standard deviation reached the value of 2.497. The lowest dispersion of values was recorded in the logistics process-material handling; the standard deviation reached the value of 2.017 .

Table 4. Descriptive statistics.

\begin{tabular}{ccccccc}
\hline & \multicolumn{2}{c}{ Frequency } & & & \\
\cline { 2 - 3 } & Absolute & Relative & Mean & Median & Mode & Std. Deviation \\
\hline $\begin{array}{c}\text { Inventory } \\
\text { management }\end{array}$ & 9 & $5.3 \%$ & 1.14 & 0 & 0 & 2.143 \\
$\begin{array}{c}\text { Material handling } \\
\text { Warehousing and }\end{array}$ & 21 & $13.1 \%$ & 1.55 & 1 & 0 & 2.017 \\
$\begin{array}{c}\text { storage } \\
\text { Packaging }\end{array}$ & 50 & $30.3 \%$ & 2.68 & 2 & 2 & 2.169 \\
$\begin{array}{c}\text { Traffic and } \\
\text { transportation }\end{array}$ & 43 & $26 \%$ & 2.35 & 2 & 2 & 2.497 \\
Source: own processing. & 42 & $25.3 \%$ & 2.28 & 1 & 1 & 2.407 \\
\hline
\end{tabular}

When implementing elements of environmental policy into logistics processes, enterprises in Slovakia face barriers that do not allow all logistics processes. The analysed enterprises in Slovakia consider the lack of financial resources for implementation of the environmental logistics elements to be the biggest barrier. The research sample rated this option with a share $33.7 \%$. Respondents also expressed their opinion that the administrative burden in implementing elements of environmental policy into logistics processes is also a problem, allotting it a share of $30.5 \%$. The least frequently $(6.2 \%)$ indicated possibility was lack of the staff dealing with the issue in the enterprise.

The authors provide descriptive statistics based on the respondents' replies in Table 5. The highest value of the median value (3.71) was achieved by the option-lack of financial resources. The smallest value of the mean value (1.13) was achieved to the response-lack of staff. The mode reached the highest value (3) in the option-the enterprise feels an 
administrative burden. The smallest value of the mode value (0) was recorded by the response-lack of staff. The median reached the highest value (2.5) in the option-the enterprise does not have financial resources and in the option-the enterprise feels an administrative burden. The median value received the lowest value (0) in the responsethe enterprise does not have sufficient staff. The highest value of standard deviation (2.117) was achieved by the option-the enterprise does not have financial resources. The lowest value of standard deviation (1.642) was reached by the response- the enterprise does not have sufficient staff.

Table 5. Descriptive statistics.

\begin{tabular}{|c|c|c|c|c|c|c|}
\hline & \multicolumn{2}{|c|}{ Frequency } & \multirow{2}{*}{ Mean } & \multirow{2}{*}{ Median } & \multirow{2}{*}{ Mode } & \multirow{2}{*}{ Std. Deviation } \\
\hline & Absolute & Relative & & & & \\
\hline $\begin{array}{l}\text { Lack of financial } \\
\text { resources }\end{array}$ & 56 & $33.7 \%$ & 3.71 & 2.5 & 2 & 2.117 \\
\hline Lack of the staff & 10 & $6.2 \%$ & 1.13 & 0 & 0 & 1.642 \\
\hline $\begin{array}{l}\text { Lack of support from } \\
\text { the government }\end{array}$ & 49 & $29.6 \%$ & 2.71 & 2 & 1 & 2.054 \\
\hline $\begin{array}{l}\text { Administrative } \\
\text { burden }\end{array}$ & 50 & $30.5 \%$ & 3.55 & 2.5 & 3 & 1.993 \\
\hline
\end{tabular}

Sustainability has long been one of the most important issues. The biggest contribution to greater worldwide sustainability on the corporate level is green logistics and reverse logistics. Green logistics and reverse logistics contribute to the protection of the environment with the aim to promote ecological methods of production, distribution and logistics processes.

The research sample uses green logistics with a share of $49.5 \%$ in large enterprises. The analysed enterprises use green logistics in small enterprises with a share of $7.4 \%$. The research sample uses green logistics in production enterprises with a share of $72.3 \%$. The analysed enterprises of trade use green logistics with a share of $10 \%$. The analysed enterprises providing services use green logistics with a share of $17.7 \%$. Most analysed enterprises use green logistics in the engineering industry (22\%). The research sample of the electrical engineering industry also recorded a high percentage $(19.8 \%)$ of the green logistics application. The analysed enterprises of the glass industry admitted the lowest percentage $(0.8 \%)$ in the green logistics utilisation. The largest percentage share $(27.6 \%)$ in the green logistics implementation was achieved by analysed enterprises in the Bratislava Region. The least frequent application of green logistics (4.8\%) recorded in the analysed enterprises of the Košice Region.

Table 6 compiles descriptive statistics based on the responses of enterprises in Slovakia. The highest value of the mean value (3.23) was achieved by production enterprises in the use of green logistics. The most common value (mode $=3$ ) was achieved by production enterprises when using green logistics. Production enterprises received the highest median value (3) in the use of green logistics. The lowest value of the standard deviation (1.664) was obtained by the use of green logistics in small enterprises. The highest value of the standard deviation (2.295) was achieved via green logistics in the Košice Region.

The research sample uses reverse logistics with a share of $48.5 \%$ in large enterprises. The respondents use reverse logistics with a share of $43.2 \%$ in medium-sized enterprises. The analysed enterprises use reverse logistics with a share of $7 \%$ in small enterprises. The respondents use reverse logistics with a share of $75.8 \%$ in production enterprises. The research sample use of reverse logistics with a share of $11.2 \%$ in trade enterprises. The analysed enterprises use reverse logistics with a share of $13 \%$ in service enterprises. The analysed enterprises from the automotive industry use reverse logistics with a share of $23.9 \%$. The research sample obtained the smallest percentage $(1.2 \%)$ use of reverse logistics in the glass industry. The largest percentage share (22.3\%) in the use of reverse logistics was 
achieved by analysed enterprises in the Bratislava Region. The least frequent application of reverse logistics (7.3\%) recorded in the analysed enterprises of the Banská Bystrica Region.

Table 6. Descriptive statistics.

\begin{tabular}{|c|c|c|c|c|c|c|}
\hline \multirow{2}{*}{ The Use of Green Logistics } & \multicolumn{2}{|c|}{ Frequency } & \multirow{2}{*}{ Mean } & \multirow{2}{*}{ Median } & \multirow{2}{*}{ Mode } & \multirow{2}{*}{ Std. Deviation } \\
\hline & Absolute & Relative & & & & \\
\hline Small enterprises & 12 & $7.4 \%$ & 2.00 & 2 & 1 & 1.664 \\
\hline Medium-sized enterprises & 71 & $43.1 \%$ & 2.41 & 2 & 1 & 1.928 \\
\hline Large enterprises & 82 & $49.5 \%$ & 2.78 & 2 & 2 & 1.713 \\
\hline Production enterprises & 119 & $72.3 \%$ & 3.23 & 3 & 3 & 1.780 \\
\hline Trade enterprises & 17 & $10 \%$ & 2.34 & 2 & 0 & 1.798 \\
\hline Service enterprises & 29 & $17.7 \%$ & 3.08 & 2 & 1 & 1.9 cur29 \\
\hline Engineering Industry & $36 \%$ & $22 \%$ & 3.20 & 2 & 2 & 1.772 \\
\hline $\begin{array}{l}\text { Electrical Engineering } \\
\text { Industry }\end{array}$ & $33 \%$ & $19.8 \%$ & 2.96 & 2 & 2 & 1.695 \\
\hline Glass Industry & $1 \%$ & $0.8 \%$ & 0,75 & 1 & 0 & 2.121 \\
\hline Bratislava Region & $46 \%$ & $27.6 \%$ & 3.17 & 2 & 2 & 1.840 \\
\hline Košice Region & $8 \%$ & $4.8 \%$ & 1.88 & 1 & 0 & 2.295 \\
\hline
\end{tabular}

Source: own processing.

Descriptive statistics are compiled in Table 7 according to the enterprises' responses. The highest value of The mean value (3.5) was achieved by production enterprises in the use of reverse logistics. Production enterprises reached the highest median value (3) in the Bratislava Region. The lowest standard deviation value (1.140) was recorded by the glass industry in the use of reverse logistics. The highest standard deviation value (2.431) was obtained by trade enterprises in the use of reverse logistics.

Table 7. Descriptive statistics.

\begin{tabular}{|c|c|c|c|c|c|c|}
\hline \multirow{2}{*}{ The Use of Reverse Logistics } & \multicolumn{2}{|c|}{ Frequency } & \multirow{2}{*}{ Mean } & \multirow{2}{*}{ Median } & \multirow{2}{*}{ Mode } & \multirow{2}{*}{ Std. Deviation } \\
\hline & Absolute & Relative & & & & \\
\hline Small enterprises & 12 & $7 \%$ & 2.36 & 1 & 0 & 2.023 \\
\hline Medium-sized enterprises & 71 & $43.2 \%$ & 2.45 & 1 & 1 & 1.827 \\
\hline Large enterprises & 82 & $49.8 \%$ & 2.73 & 2 & 2 & 1.951 \\
\hline Production enterprises & 125 & $75.8 \%$ & 3.50 & 3 & 3 & 1.772 \\
\hline Trade enterprises & 18 & $11.2 \%$ & 2.27 & 1 & 0 & 2.431 \\
\hline Service enterprises & 22 & $13 \%$ & 2.53 & 1 & 0 & 2.142 \\
\hline Automotive Industry & 39 & $23.9 \%$ & 3 & 2 & 1 & 1.944 \\
\hline Glass Industry & 2 & $1.2 \%$ & 1.4 & 0 & 0 & 1.140 \\
\hline Bratislava Region & 37 & $22.3 \%$ & 3.0 & 2.5 & 2 & 2.177 \\
\hline Banská Bystrica Region & 12 & $7.3 \%$ & 2.13 & 0.5 & 0 & 1.916 \\
\hline
\end{tabular}

Source: own processing.

According to the results of the questionnaire, the application of green logistics and reverse logistics allows enterprises to improve their customer-supplier relationships. Respondents allotted this option the highest share of $35.2 \%$. By implementing green and reverse logistics, $31.5 \%$ of the analysed enterprises in Slovakia also improve their relations with the government. The lowest percentage of analysed enterprises (6.7\%) utilise green and reverse logistics to improve their image.

Authors provides descriptive statistics based on the respondents' replies in the Table 8. The highest value of the mean value (3.2) was for the option-improving customer-supplier relations. The smallest value of the mean value (1.14) was obtained for the optionimproving the image of the enterprise. Modus value achieved the highest value (2) in the option-improving customer-supplier relations and also in the response-improving relations with the government. The median value reached the highest value of (2) in the option-improving customer-supplier relations and also in the option-improving 
relations with the government. The highest value of the standard deviation (2.302) was recorded by the option-improving the profile of enterprise on the international market. The lowest value of the standard deviation (1.963) reveals by the response-improving relations with the government.

Table 8. Descriptive statistics.

\begin{tabular}{|c|c|c|c|c|c|c|}
\hline & \multicolumn{2}{|c|}{ Frequency } & \multirow{2}{*}{ Mean } & \multirow{2}{*}{ Median } & \multirow{2}{*}{ Mode } & \multirow{2}{*}{ Std. Deviation } \\
\hline & Absolute & Relative & & & & \\
\hline Building sustainable development & 29 & $17.8 \%$ & 1.55 & 1 & 0 & 2.017 \\
\hline $\begin{array}{l}\text { To improve the profile of enterprise on the } \\
\text { international market }\end{array}$ & 15 & $8.8 \%$ & 1.60 & 1 & 0 & 2.302 \\
\hline To improve image & 11 & $6.7 \%$ & 1.14 & 0 & 0 & 2.143 \\
\hline To improve customer-supplier relationships & 58 & $35.2 \%$ & 3.2 & 2 & 2 & 2.098 \\
\hline To improve relations with the government & 52 & $31.5 \%$ & 2.95 & 2 & 2 & 1.963 \\
\hline
\end{tabular}

Source: own processing.

\subsection{Research Hypothesis 1}

The development of industrial revolutions, technical progress and consumer behaviour have affected the environment. The enterprises promoting sustainable development strive to improve green logistics. The main reason is the ecological thinking of enterprises and development of business programmes with the aim of maintaining their competitiveness in the future.

The hypothesis is based on study by DB Schenker. The main aim of enterprise is to reduce emissions by $20 \%$ by the end of 2020 . Enterprise plans to shift $50 \%$ of land freight to rail freight and ocean freight by 2050, with more than 5000 trains a day. Enterprise plans to replace $40 \%$ of fuel in air freight with biofuels. Logistics in urban centers will thus be without carbon dioxide production and ocean freight will reduce its emissions production by $40 \%$ [60].

The hypothesis is also based on Deutsche Go DHL Group's GoGreen environmental program. The aim of enterprise is in the field of climate protection is to reduce all emissions related to logistics to zero by 2050. Deutsche Post DHL Group determined the following aims by 2025: increase carbon efficiency by $50 \%$ compared to 2007 levels; reduce local air pollution emissions by operating $70 \%$ of first and last mile business services through clean pick-up and delivery solutions such as bicycles and electric cars; and derive more than $50 \%$ of the company's revenue from Green Solutions. In this way, the company wants to ensure greener supply chains for customers; and the enterprise wants to certify $80 \%$ of its employees as GoGreen specialists and involve them in business activities in the field of environmental and climate protection [61].

The hypothesis is also based on IKEA's sustainability leadership. This enterprise uses two basic materials: wood and cotton. Since 2014, more than $85 \%$ of cotton has met standards that have limited the use of water, pesticides and fertilizers. Today, $100 \%$ of the cotton used is obtained in a sustainable way. Also, the wood used by IKEA is obtained sustainably. In 2017, $75 \%$ of the wood was obtained from sustainable sources. In the following periods it will be up to $100 \%$ [62].

The tested hypothesis is written as follows:

Hypothesis $\mathbf{0}(\mathrm{H} 0)$. There is no statistically significant between the promotion of sustainable development and the improvement of green logistics in the enterprise at the significance level of $\alpha=0.05$.

Hypothesis 1 (H1). There is statistically significant between the promotion of sustainable development and the improvement of green logistics in the enterprise at the significance level of $\alpha=0.05$. 
Based on results from the questionnaire was applied $\chi^{2}$-test of goodness of fit, we created contingency table. Authors show observed values $\left(\mathrm{O}_{\mathrm{ij}}\right)$ in Table 9.

Table 9. Observed values $\left(\mathrm{O}_{\mathrm{ij}}\right)$ of hypothesis.

\begin{tabular}{cccccc}
\hline Observed Values $\mathbf{O}_{\mathbf{i j}}$ & $\mathbf{b}_{\mathbf{1}}$ & $\mathbf{b}_{\mathbf{2}}$ & $\mathbf{b}_{\mathbf{3}}$ & $\mathbf{b}_{\mathbf{4}}$ & Total \\
\hline $\mathrm{a}_{1}$ & 22 & 17 & 23 & 15 & 77 \\
$\mathrm{a}_{2}$ & 5 & 3 & 5 & 8 & 21 \\
$\mathrm{a}_{3}$ & 13 & 7 & 5 & 11 & 36 \\
$\mathrm{a}_{4}$ & 16 & 9 & 2 & 4 & 31 \\
Total & 56 & 36 & 35 & 38 & 165 \\
\hline
\end{tabular}

Source: own processing.

Expected values $\left(\mathrm{E}_{\mathrm{ij}}\right)$ from questionnaire were calculated based on relationship [59]:

$$
E_{i j}=n \cdot \frac{n i \bullet}{n} \cdot \frac{n \bullet j}{n}=\frac{n i \bullet \cdot n \bullet j}{n}
$$

where: $\mathrm{n}$-total table value

The calculated expected values from the questionnaire data are given in Table 10.

Table 10. Expected values $\left(\mathrm{E}_{\mathrm{ij}}\right)$ of hypothesis.

\begin{tabular}{cccccc}
\hline Expected Values $\mathbf{E}_{\mathbf{i j}}$ & $\mathbf{b}_{\mathbf{1}}$ & $\mathbf{b}_{\mathbf{2}}$ & $\mathbf{b}_{\mathbf{3}}$ & $\mathbf{b}_{\mathbf{4}}$ & Total \\
\hline $\mathrm{a}_{1}$ & 26.13 & 16,80 & 16.33 & 17.73 & 77 \\
$\mathrm{a}_{2}$ & 7.13 & 4,58 & 4.45 & 4.84 & 21 \\
$\mathrm{a}_{3}$ & 12.22 & 7.85 & 7.64 & 8.29 & 36 \\
$\mathrm{a}_{4}$ & 10.52 & 6.76 & 6.58 & 7.14 & 31 \\
Total & 56 & 36 & 35 & 38 & 165 \\
\hline
\end{tabular}

Source: own processing.

Condition that $80 \%$ of expected frequencies $\left(\mathrm{E}_{\mathrm{ij}}\right)$ must be higher than 5 was fulfilled to $81 \%$. We can see this fact in Table 11. Subsequently, we proceeded to test the hypothesis

Table 11. Chi-squared of hypothesis.

\begin{tabular}{cccccc}
\hline Chi-Squared & $\mathbf{b}_{\mathbf{1}}$ & $\mathbf{b}_{\mathbf{2}}$ & $\mathbf{b}_{\mathbf{3}}$ & $\mathbf{b}_{\mathbf{4}}$ & Total \\
\hline $\mathrm{a}_{1}$ & 0.65 & 0.00 & 2.72 & 0.42 & 3.80 \\
$\mathrm{a}_{2}$ & 0.63 & 0.55 & 0.07 & 2.07 & 3.32 \\
$\mathrm{a}_{3}$ & 0.05 & 0.09 & 0.91 & 0.89 & 1.94 \\
$\mathrm{a}_{4}$ & 2.85 & 0.74 & 3.18 & 1.38 & 8.16 \\
Total & 4.19 & 1.38 & 6.88 & 4.76 & 17.21 \\
\hline
\end{tabular}

Source: own processing.

Was counted up all rows and columns and in the right bottom corner was identified square contingency $($ chi-squared $)=17.21$.

Calculated testing characteristics were compared with 95 percentile $\chi^{2}$-division with $(r-1) \cdot(s-1)=(4-1) \cdot(4-1)=9$ degrees of freedom $\chi^{2}{ }_{0.95}(9)=16.919$. Calculation showed that square contingency exceeds critical value, thus is reject the null hypothesis.

On the significance level of $\alpha=0.05$ there is statistically important dependence between the promotion of sustainable development and the improvement of green logistics in the enterprise.

Based on the verification of the hypothesis, we proceeded to measure the intensity of this dependence. Pearson contingency coefficient was calculated on relationship [59]:

$$
C=\sqrt{\frac{\varnothing^{2}}{1+\varnothing^{2}}=\sqrt{\frac{\chi^{2}}{n+\chi^{2}}}}
$$


where: $\varnothing^{2}$ is an mean square contingency, it means $\varnothing^{2}=\frac{\chi^{2}}{n}$

Calculation confirmed that $C=0.3335$ (medium dependence). Pearson contingency coefficient indicates medium dependence between the promotion of sustainable development and the improvement of green logistics in the enterprise.

Tschuprow's contingency coefficient was calculated based on relationship [59]:

$$
\tau=\sqrt{\frac{\varnothing^{2}}{\sqrt{(r-1) \cdot(s-1)}}}
$$

The calculation identified $\tau=0.2043$ (medium dependence). Tschuprow's contingency coefficient indicates medium dependence between the promotion of sustainable development and the improvement of green logistics in the enterprise.

Cramer's contingency coefficient was calculated based on relationship [59]:

$$
V=\sqrt{\frac{\chi^{2}}{n \cdot h}}
$$

The calculation revealed that $V=0.2043$ (medium dependence). Cramer's contingency coefficient indicates medium dependence between the promotion of sustainable development and the improvement of green logistics in the enterprise.

\subsection{Research Hypothesis 2}

Reverse logistics is an integral part of green logistics, as together they meet the environmental objectives of enterprises. Reverse logistics combine environmental objectives with economic ones, as they seek to minimize the waste of resources, reuse products and packaging, and extend the life of products and components. The enterprise's promoting reverse logistics try to streamline their logistics processes, through e.g., the return of packaging.

The hypothesis is based on the authors Simões et al. [63], who say that reverse logistics is a much-discussed topic not only in academia or in industry itself. With an increase in the competition on a global scale coupled with concerns about the environment, reverse logistics is becoming a necessity. Managers need to consider the integration of collection, inspection and consolidation of used products with forward logistics in a reverse logistics programs.

The hypothesis is based on research by Deloitte and Arvato. This research says that reverse logistics represents a significant part of the company's cost structure. This company structure ranges from $0.1 \%$ to $1 \%$ of the value of product sales and on average $0.5 \%$. In addition, a well-managed reverse logistics flow has, on average, the potential to recover $32 \%$ of the value of the original product [64].

The hypothesis is based on research by TATA Consultancy services, which says that green packaging represents a reduction in material. The study says that it is important to realize that recycling thin or light packaging is more difficult than heavy packaging. At present, packaging represents $23 \%$ by weight of waste and $37 \%$ by volume of waste [65].

The hypothesis is based on the opinion of Lisec et al. [66], if reverse logistics is to become a function of sustainable development, conventional efficiency thinking needs to be adapted to the sustainability contest. The authors talk about the idea-Production or sale more for less together with production or processing more with less consumption, but while maintaining economic viability.

The tested hypothesis is as follows:

Hypothesis $\mathbf{0}(\mathbf{H 0} \mathbf{0})$. There is no statistically significant relationship between the use of the logistics process of packaging and the improvement of reverse logistics in the enterprise at the significance level of $\alpha=0.05$. 
Hypothesis 1 (H1). There is statistically significant relationship between the use of the logistics process of packaging and the improvement of reverse logistics in the enterprise at the significance level of $\alpha=0.05$.

Based on results from the questionnaire was applied $\chi^{2}$-test of goodness of fit, we created a contingency table. The observed values $\left(\mathrm{O}_{\mathrm{ij}}\right)$ are shown in Table 12.

Table 12. Observed values $\left(\mathrm{O}_{\mathrm{ij}}\right)$ of the hypothesis.

\begin{tabular}{cccccc}
\hline Observed Values $\mathbf{O}_{\mathbf{i j}}$ & $\mathbf{b}_{\mathbf{1}}$ & $\mathbf{b}_{\mathbf{2}}$ & $\mathbf{b}_{\mathbf{3}}$ & $\mathbf{b}_{\mathbf{4}}$ & Total \\
\hline $\mathrm{a}_{1}$ & 10 & 8 & 4 & 9 & 31 \\
$\mathrm{a}_{2}$ & 12 & 7 & 4 & 11 & 34 \\
$\mathrm{a}_{3}$ & 13 & 6 & 2 & 32 & 53 \\
$\mathrm{a}_{4}$ & 12 & 4 & 10 & 21 & 47 \\
Total & 47 & 25 & 20 & 73 & 165 \\
\hline
\end{tabular}

Source: own processing.

Expected values $\left(\mathrm{E}_{\mathrm{ij}}\right)$ from the questionnaire were calculated based on the relationship [59]:

$$
E_{i j}=n \cdot \frac{n i \bullet}{n} \cdot \frac{n \bullet j}{n}=\frac{n i \bullet \cdot n \bullet j}{n}
$$

where: $\mathrm{n}$-total table value

The calculated expected values from the questionnaire data are given in Table 13.

Table 13. Expected values $\left(\mathrm{E}_{\mathrm{ij}}\right)$ of hypothesis.

\begin{tabular}{cccccc}
\hline $\begin{array}{c}\text { Expected } \\
\text { Values } \mathbf{E}_{\mathbf{i j}}\end{array}$ & $\mathbf{b}_{\mathbf{1}}$ & $\mathbf{b}_{\mathbf{2}}$ & $\mathbf{b}_{\mathbf{3}}$ & $\mathbf{b}_{\mathbf{4}}$ & Total \\
\hline $\mathrm{a}_{1}$ & 8.83 & 4.70 & 3.76 & 13.72 & 31 \\
$\mathrm{a}_{2}$ & 9.68 & 5.15 & 4.12 & 15.04 & 34 \\
$\mathrm{a}_{3}$ & 15.10 & 8.03 & 6.42 & 23.45 & 53 \\
$\mathrm{a}_{4}$ & 13.39 & 7.12 & 5.70 & 20.79 & 47 \\
Total & 47 & 25 & 20 & 73 & 165 \\
\hline Source: own processing. & & & &
\end{tabular}

The condition that $80 \%$ of expected frequencies $\mathrm{E}_{\mathrm{ij}}$ must be higher than 5 was fulfilled to $88 \%$. We can see this fact in Table 14 . Subsequently, we proceeded to test the hypothesis.

Table 14. Chi-squared of hypothesis

\begin{tabular}{cccccc}
\hline Chi-Squared & $\mathbf{b}_{\mathbf{1}}$ & $\mathbf{b}_{\mathbf{2}}$ & $\mathbf{b}_{\mathbf{3}}$ & $\mathbf{b}_{\mathbf{4}}$ & Total \\
\hline $\mathrm{a}_{1}$ & 0.15 & 2.32 & 0.02 & 1.62 & 4.11 \\
$\mathrm{a}_{2}$ & 0.55 & 0.66 & 0.00 & 1.09 & 2.31 \\
$\mathrm{a}_{3}$ & 0.29 & 0.51 & 3.05 & 3.12 & 6.97 \\
$\mathrm{a}_{4}$ & 0.14 & 1.37 & 3.25 & 0.00 & 4.76 \\
Total & 1.14 & 4.87 & 6.32 & 5.83 & 18.16 \\
\hline
\end{tabular}

Source: own processing.

We counted up all rows and columns and in the right bottom corner identified square contingency (chi-squared) $=18.16$.

The calculated testing characteristics were compared with 95 percentile $\chi^{2}$-division with $(r-1) \cdot(s-1)=(4-1) \cdot(4-1)=9$ degree of freedom $\chi^{2} 0.95(9)=16.919$. The calculation showed that square contingency exceeds critical value, thus the null hypothesis is rejected.

On the significance level of $\alpha=0.05$ there is statistically important dependence between the use of the logistics process of packaging and the improvement of reverse logistics in the enterprise. 
Based on verification hypothesis was measured intensity of this dependence. Pearson contingency coefficient was calculated on relationship [59]:

$$
C=\sqrt{\frac{\varnothing^{2}}{1+\varnothing^{2}}=\sqrt{\frac{\chi^{2}}{n+\chi^{2}}}}
$$

where: $\varnothing^{2}$ is an mean square contingency, it means $\varnothing^{2}=\frac{\chi^{2}}{n}$

Calculation confirmed that $C=0.3148$ (medium dependence). The Pearson contingency coefficient indicates medium dependence between the use of the logistics process of packaging and the improvement of reverse logistics in the enterprise.

Tschuprow's contingency coefficient was calculated based on relationship [59]:

$$
\tau=\sqrt{\frac{\varnothing^{2}}{\sqrt{(r-1) \cdot(s-1)}}}
$$

The calculation identified $\tau=0.1915$ (weak dependence). Tschuprow's contingency coefficient indicates weak dependence between the use of the logistics process of packaging and the improvement of reverse logistics in the enterprise.

Cramer's contingency coefficient was calculated based on relationship [59]:

$$
V=\sqrt{\frac{\chi^{2}}{n \cdot h}}
$$

The calculation revealed that $V=0.1915$ (weak dependence). Cramer's contingency coefficient indicates weak dependence between the use of the logistics process of packaging and the improvement of reverse logistics in the enterprise.

\section{Discussion}

Sustainability in industrial sectors plays a key role in implementation and development support in new technologies, efficient resource utilisation and in business transactions on both the local and international market. Innovations will be a driving force for the next generation of production businesses, which are competitive and sustainable. Innovations and technological advancement are considered essential in search for permanent solutions of economic and environmental challenges, such as increased resources and energetic effectiveness.

The condition of technologies, industrial infrastructure, degree of utilisation for secondary and primary materials, low devaluation of materials, raw materials and energies as well as continuous maintenance of the fleet impacts the state of the environment in the Slovak Republic. The foundation for development of sustainability is an implementation of environmental politics in a country that is based on fulfilling resolutions and goals referring to protection and repair of damage to the environment.

Based on analyses of research results we found out that $47.3 \%$ of large enterprises in Slovakia are implementing environmental politics. Out of the research sample, $76.4 \%$ of production enterprises enforces environmental politics and the high share of enterprises, $21.2 \%$, is represented by the automotive industry. These results reflect the character of the Slovak market, which is production-construction focused. One of the biggest economy boosters is an automotive industry, resulting from the fact that in Slovakia there are four worldwide automotive plants: Volkswagen Slovakia, PSA Peugeot Citroën Slovakia, Kia Motors Slovakia, and Jaguar Land Rover Slovakia. The implementation of environmental politics in Slovakia is characterised by the principle of prevention resulting in an increased attention to questions regarding the impact of products and technologies on the environment. There are new systems being implemented securing the product to be in accordance with the current condition parameters, minimise or even exclude harmful impacts on an environment. The problematic of a product preference meeting all requirements of pro- 
tection and creation of an environment within their entire lifecycle is receiving increasing attention not only from consumers, but also business subjects and associations.

Out of selected voluntary tools of environmental politics, enterprises utilise social responsibility of businesses the most. This means focusing on customers while considering attributes of an environment protection. Enterprises state that social responsibility manifests itself in form of short delivery time, payment discipline, minimal waste and utilisation of recycled packaging.

The principles of environmental politics also impact corporate logistics. Production logistics is the most impacted by environmental politics. Enterprises selected this option have a share of $37.7 \%$. Responsible production might be expressed by certain delivery of certified quality product to the customer. Certified products meet construction norms, and maintain and improve management systems of health and safety regulations and environment. The aim is to eliminate the risk of new work-related injury and harmed health, decreased amount of waste created, increased share in their recycling and minimisation of harmful influence on an environment. Production sustainability consists in the ability to create such a production program where there will be such products that are demanded on a market and at the same time that have chosen such production means, production systems and processes that allow securing a production program from the point of a market. Production sustainability represents a specific area which considers correct construction of production program and sustainability from the point of demand for products.

Distribution logistics of analysed enterprises is influenced by the environment by a share of $33.9 \%$. Within fulfilling principles of social responsibility in sphere of packaging and transportation there is a very important responsible selection of suppliers capable of supplying sustainable and ecological components, materials and products. In logistics, these are represented by more efficient transportation, more ecological packaging in form of recyclable cartons, collection, recycling and reusing of paper.

Based on assessed percentages shares we can see that enterprises enforce elements of environmental politics in logistics process of storage the most. Within EMAS which is utilised by $22.7 \%$ of enterprises, this assesses for example disposing of fuels and chemicals, product supplies, storage within the building and outside the building with an aim of eliminating uncontrollable waste, lights in storage rooms, and automatic entrance gate via environmental maps with an aim to save energy. Energy utilisation in individual areas of business is influenced by different uses of technologies, processes and products, energy resources and prices, politics, economics and the business situation. In terms of dealing with waste, businesses focus on waste separating, storing waste outside buildings, disposal of goods packaging. The aforementioned activities belong to the process of packaging in researched enterprises with a share of $26 \%$. The objective of sustainable logistics of packaging is to secure financial efficiency, a degree of service level fulfilment, energy consumption, resource consumption, level of emissions, effective utilisation of space, work environment-absence rate and security—and injury rate.

When implementing elements of environmental politics into logistics processes, enterprises come across such barriers as lack of financial resources for implementation of elements of environmental logistics by a share of $33.7 \%$, and the administrative load for businesses in implementing elements of environmental politics into logistics processes has the share $30.5 \%$.

Nowadays sustainable development is becoming one of the priorities in the business sphere. The biggest contribution towards better sustainability in the world on a business level is a green logistics and reverse logistics. Green logistics and reverse logistics contribute towards environmental protection with an aim to support ecological means of production, distribution and logistics processes. The foundation of Green logistics is connection of logistics activities with ecological goals of business, which represent the result of synchronisation and optimisation of information and material flows aimed at customer satisfaction with consideration for soundness of expenses and minimising negative impacts on an environment. Within logistics, we are able to see an advancement in development 
of utilising renewable energy resources, more ecological forms of packaging materials, more ecological means of transportation and also reverse processing and recycling of used products. Businesses, aiming at improving their competitive abilities and securing the good name of their business in local and foreign markets, are leaning towards utilising tools of the environment in the form of decreasing negative transportation impacts by transferring from air transportation to truck or rail transportation, and utilisation of hybrid and electric vehicles etc.

Green logistics is adopted mainly by large enterprises with a share of $49.5 \%$ and reverse logistics is utilised in a share $48.9 \%$. In assessment of analysed enterprises, we can see a close relation between two logistics trends such as part of the sustainable development of enterprises in Slovakia. In an industrial sector, production enterprises implement green logistics with a share of $72.3 \%$ and reverse logistics with a share of $75.8 \%$. Sustainability of green logistics can be achieved by efficient utilisation of energies in a suitable selection of energy resources, decreased energy expenses, repeated energy use. In the preparation process, aiming to monitor sustainable logistics there is monitoring of such criteria as transportation costs, delivery time, waste of energy and materials, greenhouse gas emissions, time delays due to traffic, human toxicity, level of absence and injuries at a workplace. Reverse logistics is an inseparable part of green logistics which deals mainly with recycling and managing products and packaging after their lifecycle. It includes activities like claim, recycling, repeated use or disposing of product in a way that is considerate to an environment.

Sustainability and its development have slowed down due to the continuous decrease of global growth. Currently one of the main causes is considered to be the COVID-19 pandemic, which has disrupted global value chains, product supplies, significantly affected production sectors and changed the business environment. Corona virus pandemics has revealed strong points and weaknesses in innovation implementation, critical points in infrastructure and supply chain management. The current pandemic situation creates space for research in logistics in the future, especially in development and implementation of innovations and introducing changes invoked by pandemic crises, which appeared in the supplier/customer relationship in individual processes of acquisition, production and distribution logistics.

\section{Conclusions}

In the future, we can see the direction of sustainable development in logistics in terms of the continuous implementation of ecological tools, innovations and engineering into enterprises and the production and service sectors. This is about acquiring a competitive tool not only in the field of economic aspects, within domestic and foreign markets, but also about the ethical responsibility of enterprises and its employees. Sustainability is strategically achievable if enterprises and society start to think and work ecologically. We can state that, at present, enterprises are increasingly trying to behave ecologically, not only because of regulations and laws, but they are developing this area within the corporate culture and as part of the code of ethics of enterprises and institutions.

The research carried out in the Slovak Republic on a sample of 165 enterprises showed the following facts. Environmental policy is used mainly by large enterprises in Slovakia $(47.3 \%)$, which operate as production enterprises $(76.4 \%)$. Of the analysed enterprises in Slovakia, enterprises in the automotive industry use the environmental policy the most $(21.2 \%)$. Of the regions of Slovakia, the environmental policy is mostly used by analysed enterprises based in the Trnava Region (22.8\%). Of the environmental policy instruments, analysed enterprises in Slovakia use the most voluntary instruments (35.5\%). Of the selected voluntary instruments of environmental policy, analysed enterprises in Slovakia use corporate social responsibility the most (29.8\%). Under the influence of the environment, production logistics in analysed enterprises in Slovakia are the most used $(37.7 \%)$. Analysed enterprises in Slovakia mostly promote elements of environmental policy in the logistics process-warehousing and storage (30.3\%). When implementing 
elements of environmental policy, the analysed enterprises in Slovakia consider the lack of financial resources for the implementation of elements of environmental logistics to be the biggest barrier (33.7\%). Green logistics is mostly used by large enterprises $(49.5 \%)$ and production enterprises $(72.3 \%)$. Green logistics is mostly used by analysed enterprises from the engineering industry (22\%) and enterprises operating in the Bratislava Region $(27.6 \%)$. Of the analysed enterprises in Slovakia, large enterprises $(48.9 \%)$ and production enterprises $(75.8 \%)$ use reverse logistics the most. Reverse logistics is used mainly by analysed enterprises from the automotive industry (23.9\%) and enterprises operating in the Bratislava Region (22.3\%). The implementation of green logistics and reverse logistics enables analysed enterprises in Slovakia to improve customer-supplier relations (35.2\%).

The presented results represent the current state of green and reverse logistics in enterprises in Slovakia. These results can help at the national level-the departments of spatial planning and the environment in higher territorial units in Slovakia in the formation and creation of tools and strategies of environmental policy in individual regions of Slovakia. The results of the research from the article can also be used by the Ministry of the Environment of the Slovak Republic in creating a report on the state of the environment and in creating studies on the environment in the business environment. Within Slovakia, this institution formulates and sets the direction of the environment and cooperates with the European Union in the creation of programs created by the European Commission.

Research conducted around the world shows the following facts. Simões et al. [63] carried out a survey of 225 enterprises in Portugal. The results of the survey showed that Portuguese enterprises consider the implementation of reverse logistics to be at a strategic level. The survey showed that the reasons for implementing reverse logistics include: improving customer satisfaction, reducing logistics costs, legal requirements, recovering the value of returned products, increasing competitiveness, reducing inventory, and product life cycle. The survey also infected obstacles in the implementation of reverse logistics: lack of interest on the part of decision-makers, financial constraints, lack of technological systems, lack of training. When using reverse logistics, enterprises in Portugal (53.5\%) experienced economic benefits in the form of improved logistics efficiency and reduced logistics costs. Portuguese enterprises have invested in the development of reverse logistics in the form of electronic data interchange (EDI), reverse logistics (RL) software and other new logistics resources. Martins et al. [67] analysed sustainability reports published by enterprises in Brazil. They compiled sustainable practices developed by enterprises grouped into five macro-areas. The first area deals with the choice of mode of transport, and use of vehicles. The second area deals with warehousing, the third area concerns suppliers and purchasing processes. The fourth area concerns packaging processes and the fifth area sustainable management practices and social programs. An interesting finding was the selection of the supplier with regard to its environmental practices, compliance with labor standards, code of conduct, anti-corruption program and sustainable certifications. This practice was developed by $57 \%$ of enterprises in the sample. Trivellas et al. [7] conducted the research through a structured questionnaire with 134 executives of enterprises in the agri-food sector in Greece. Research has shown that information sharing, logistics networks and transport are the strongest factors influencing the sustainable performance of a business and supply chain. In addition, green packaging is related to aspects of financial and social performance. Vazifehdan and Darestani [68] performed a case study in enterprise from the petrochemical industry. The aim of the study was to create a model for evaluating the green logistics of outsourcing. The results of the model showed that in the first place are convenient and suitable logistics services, in the second place the implementation of transport infrastructure for environmental policies, and in the third place the necessary expertise and experience in similar sectors.

A further direction in this area can be an incentive to explore a deeper analysis of green and reverse logistics in individual countries of the European Union and in the world. There is currently a lack of studies and publications that address the complex state and comparison of green and reverse logistics at the business level in the world and in the 
European Union. The studies are only partial and cover only one country. It is for this reason that space is created for the cooperation of several countries in the creation of studies and publications that can provide businesses with the current state of the issue.

The results of the paper give impetus for the establishment of better conditions within the economic instruments of environmental policy and legislative instruments of environmental policy in Slovakia. The Ministry of the Environment of the Slovak Republic, together with the Slovak Environment Agency, should adjust these environmental tools to make them more interesting, implemented more, and used for enterprises. It is also very important to encourage the use of green and reverse logistics in small enterprises in Slovakia and other types of industry in Slovakia. This can be achieved through incentives, subsidies, government benefits and greater promotion at the national level. Small enterprises have an irreplaceable place in the economy of the Slovak Republic. For this reason, it is essential to involve them in the use of green and reverse logistics. It is also important that other types of industry in Slovakia use green and reverse logistics to a greater extent. The results of the research revealed that green and reverse logistics in western Slovakia are the most widely used in Slovakia. The reason is the excellent transport infrastructure and the close location between the three countries of the Visegrad Group. The results of research can be used by enterprises in creating and innovating corporate environmental policy. Businesses in Slovakia can also use the results to set up a circular economy. The principles of sustainability bring differentiation of the product offer and further integration of the entire product value chain and subsequent change of the logistics chain.

Author Contributions: Conceptualization, P.R. and K.G.; methodology, P.R.; statistical analysis, P.R.; validation, P.R. and K.G.; formal analysis, P.R. and K.G.; investigation, P.R.; resources, K.G.; data curation, P.R.; writing — original draft preparation, P.R. and K.G.; writing-review and editing, P.R. and K.G.; visualization, P.R.; supervision, K.G.; project administration, P.R.; funding acquisition, P.R. All authors have read and agreed to the published version of the manuscript.

Funding: This research was funded by a grant-VEGA, No. 1/0375/20-New dimension in the development of production management and logistics under the influence of Industry 4.0 in enterprises in Slovakia.

Institutional Review Board Statement: Not applicable.

Informed Consent Statement: Not applicable.

Acknowledgments: This research was supported by the Scientific Grant Agency of the Ministry of Education, Science, Research and Sport of the Slovak Republic and the Slovak Academy of Sciences VEGA, Project No. 1/0375/20-New dimension in the development of production management and logistics under the influence of Industry 4.0 in enterprises in Slovakia.

Conflicts of Interest: The authors declare no conflict of interest. The funders had no role in the design of the study; in the collection, analyses, or interpretation of data; in the writing of the manuscript; or in the decision to publish the results.

\section{References}

1. Yang, C.J.; Chen, J.L. Accelerating preliminary eco-innovation design for products that integrates case-based reasoning and TRIZ method. J. Clean. Prod. 2011, 19, 998-1006. [CrossRef]

2. Maciková, L.; Smorada, M.; Dorčák, P.; Beug, B.; Markovič, P. Financial Aspects of Sustainability: An Evidence from Slovak Companies. Sustainability 2018, 10, 2274. [CrossRef]

3. Galbraith, B.; McAdam, R.; Woods, J.; McGowan, T. Putting Policy into Practice: An Exploratory Study of SME Innovation Support in a Peripheral UK Region. Entrep. Reg. Dev. 2017, 29, 668-691. [CrossRef]

4. Mathiyazhagan, K.; Govindan, K.; NoorulHaq, A.; Geng, Y. An ISM approach for the barrier analysis in implementing green supply chain management. J. Clean. Prod. 2013, 47, 283-297. [CrossRef]

5. Ren, R.; Hu, W.; Dong, J.; Sun, B.; Chen, Y.; Chen, Z. A Systematic Literature Review of Green and Sustainable Logistics: Bibliometric Analysis, Research Trend and Knowledge Taxonomy. Int. J. Environ. Res. Public Health 2020, 17, 261. [CrossRef]

6. Wang, D.-F.; Dong, Q.-L.; Peng, Z.-M.; Khan, S.; Tarasov, A. The Green Logistics Impact on International Trade: Evidence from Developed and Developing Countries. Sustainability 2018, 10, 2235. [CrossRef] 
7. Trivellas, P.; Malindretos, G.; Reklitis, P. Implications of Green Logistics Management on Sustainable Business and Supply Chain Performance: Evidence from a Survey in the Greek Agri-Food Sector. Sustainability 2020, 12, 10515. [CrossRef]

8. Björklund, M.; Forslund, H. Challenges Addressed by Swedish Third-Party Logistics Providers Conducting Sustainable Logistics Business Cases. Sustainability 2019, 11, 2654. [CrossRef]

9. Persdotter, I.M.; Hulthén, H.; Forslund, H. Environmentally Sustainable Logistics Performance Management Process Integration between Buyers and 3PLs. Sustainability 2019, 11, 3061. [CrossRef]

10. Kaur, H.; Singh, S.P. Sustainable procurement and logistics for disaster resilient supply chain. Ann. Oper. Res. 2019, 283, 309-354. [CrossRef]

11. Shaofei, J.; Feng, D.; Lu, C.A. Sustainable Innovation-Additional Services for Products Based on Personalised Customer Value. Sustainability 2019, 11, 1763. [CrossRef]

12. Hall, J.; Daneke, G.; Lenox, M. Sustainable development and entrepreneurship: Past contributions and future directions. J. Bus. Ventur. 2010, 25, 439-448. [CrossRef]

13. Hörisch, J.; Kollat, J.; Brieger, S. What influences environmental entrepreneurship? A multilevel analysis of the determinants of entrepreneurs' environmental orientation. Small Bus. Econ. 2017, 48, 47-69. [CrossRef]

14. Juan, Z. R\&D for environmental innovation and supportive policy: The implications for new energy automobile industry in China. Energy Procedia 2011, 5, 1003-1007. [CrossRef]

15. Markard, J.; Raven, R.; Truffer, B. Sustainability transitions: An emerging field of research and its prospects. Res. Policy 2012, 41, 955-967. [CrossRef]

16. Gartner. SCM World Future of Supply Chain. Available online: http://www.scmworld.com/wpcontent/uploads/2017/07/ Future_of_Supply_Chain_2016_.pdf (accessed on 5 October 2020).

17. Carrion-Flores, C.E.; Innes, R. Environmental innovation and environmental performance. J. Environ. Econ. Manag. 2010, 59, 27-42. [CrossRef]

18. Garrette, C.; Justin, K.; Long, N.H.; Marcel, C. Design for Sustainability: Current Trends in Sustainable Product Design and Development. Sustainability 2009, 1, 409-424. [CrossRef]

19. Dangelico, R.M.; Pujari, D. Mainstreaming green product innovation: Why and how companies integrate environmental sustainability. J. Bus. Ethics 2010, 95, 471-486. [CrossRef]

20. Frenken, K.; Faber, A. Introduction: Evolutionary methodologies for analyzing environmental innovations and the implications for environmental policy. Technol. Forecast. Soc. Chang. 2009, 76, 449-452. [CrossRef]

21. Rave, T.; Goetzke, F.; Larch, M. The determinants of Environmental Innovations and patenting: Germany Reconsidered. In IFO Working Paper No. 97; Munich, Germany, February 2011; Available online: https:/ /www.ifo.de/DocDL/IfoWorkingPaper-97.pdf (accessed on 7 October 2020).

22. Pacheco, D.; Dean, T.; Payne, D. Escaping the green prison: Entrepreneurship and the creation of opportunities for sustainable development. J. Bus. Ventur. 2010, 25, 464-480. [CrossRef]

23. Muñoz-Pascual, L.; Curado, C.; Galende, J. The Triple Bottom Line on Sustainable Product Innovation Performance in SMEs: A Mixed Methods Approach. Sustainability 2019, 11, 1689. [CrossRef]

24. Kildiene, S.; Zavadskas, E.K.; Tamošaitiene, J. Complex assessment model for advanced technology deployment. J. Civ. Eng. Manag. 2014, 20, 280-290. [CrossRef]

25. OECD. OECD Economic Outlook. Available online: https://doi.org/10.1787/eco_outlook-v2003-1-en (accessed on 13 October 2020).

26. Seroka-Stolka, O.; Ociepa-Kubicka, A. Green logistics and circular economy. Transp. Res. Procedia 2019, 39, 471-479. [CrossRef]

27. Jastrzębska, E. Circular economy-A new idea or the old approach? Good practices of socially responsible companies. Pr. Nauk. Uniw. Ekon. We Wrocławiu. 2017, 491, 220-234. [CrossRef]

28. Bask, A.; Rajahonka, M. The Role of Environmental Sustainability in the Freight Transport Mode Choice. Int. J. Phys. Distrib. Logist. Manag. 2017, 47, 560-602. [CrossRef]

29. Jiang, J.; Zhang, D.; Li, S.; Liu, Y. Multimodal Green Logistics Network Design of Urban Agglomeration with Stochastic Demand. J. Adv. Transp. 2019, 2019, 1-19. [CrossRef]

30. Huang, J.; Shuai, Y.; Liu, Q.; Zhou, H.; He, Z. Synergy Degree Evaluation Based on Synergetics for Sustainable Logistics Enterprises. Sustainability 2018, 10, 2187. [CrossRef]

31. Polychroniou, P.; Trivellas, P. The Impact of Strong and Balanced Organizational Cultures on Firm Performance. Int. J. Qual. Serv. Sci. 2018, 10, 16-35. [CrossRef]

32. Ni, S.; Lin, Y.; Li, Y.; Shao, H.; Wang, S. An Evaluation Method for Green Logistics System Design of Agricultural Products: A Case Study in Shandong Province, China. Adv. Mech. Eng. 2019, 11, 168781401881687. [CrossRef]

33. Rakhmangulov, A.; Sladkowski, A.; Osintsev, N.; Muravev, D. Zelena Logistika: Sustav Metoda i Instrumenata-2. Dio. Naše More 2018, 65, 49-55. [CrossRef]

34. Helo, P.; Ala-Harja, H. Green Logistics in Food Distribution-A Case Study. Int. J. Logist. Res. Appl. 2018, 21, 464-479. [CrossRef]

35. Mckinnon, A.; Browne, M.; Whiteing, A.; Piecyk, M. Green Logistics Improving the Environmental Sustainability of Logistics; Kogan Page: London, UK, 2015; 448p.

36. Teixeira, C.R.B.; Assumpção, A.L.; Correa, A.L.; Savi, A.F.; Prates, G.A. The Contribution of Green Logistics and Sustainable Purchasing for Green Supply Chain Management. Indep. J. Manag. Prod. 2018, 9, 1002. [CrossRef] 
37. Cherrafi, A.; Garza-Reyes, J.A.; Kumar, V.; Mishra, N.; Ghobadian, A.; Elfezazi, S. Lean, Green Practices and Process Innovation: A Model for Green Supply Chain Performance. Int. J. Prod. Econ. 2018, 206, 79-92. [CrossRef]

38. Dubey, V.K.; Chavas, J.P.; Veeramani, D. Analytical Framework for Sustainable Supply-Chain Contract Management. Int. J. Prod. Econ. 2018, 200, 240-261. [CrossRef]

39. Genovese, A.; Morris, J.; Piccolo, C.; Koh, S.C.L. Assessing Redundancies in Environmental Performance Measures for Supply Chains. J. Clean. Prod. 2017, 167, 1290-1302. [CrossRef]

40. Govindan, K.; Soleimani, H.; Kannan, D. Reverse Logistics and Closed-Loop Supply Chain: A Comprehensive Review to Explore the Future. Eur. J. Oper. Res. 2015, 240, 603-626. [CrossRef]

41. Gang, X. Modeling decision processes of a green supply chain with regulation on energy saving level. Comput. Oper. Res. 2015 54, 266-273.

42. Dukić, G.; Česnik, V.; Opetuk, T. Order-picking Methods and Technologies for Greener Warehousing. Strojarstvo 2010, 52, 23-31. [CrossRef]

43. Lee, S.; Kim, S.T.; Choi, D. Green supply chain management and organizational performance. Ind. Manag. Data Syst. 2012, 112, 1148-1180. [CrossRef]

44. Ochieng, O.S.; Awino, Z.B.; Njihia, M.J.; Iraki, W.N. Green Supply Chain Management Practices and Performance of ISO 14001 Certified Manufacturing FIRMS in East Africa. Dba Afr. Manag. Rev. 2016, 6, 103-128. [CrossRef]

45. Eltayeb, T.K.; Zailani, S.; Ramayah, T. Green supply chain initiatives among certified companies in Malaysia and environmental sustainability: Investigating the outcomes. Resour. Conserv. Recycl. 2011, 55, 495-506. [CrossRef]

46. Mitra, S.; Datta, P.P. Adoption of green supply chain management practices and their impact on performance: An exploratory study of Indian manufacturing firms. Int. J. Prod. Res. 2014, 52, 2085-2107. [CrossRef]

47. Grant, D.B.; Trautrims, A.; Wong, C.Y. Sustainable Logistics and Supply Chain Management; Kogan Page: London, UK, 2015; 304p.

48. Pozo, H.; Akabane, G.K.; Tachizava, T. Innovation and technology processes in micro and small business. Cogent Bus. Manag. 2019, 6, 1-20. [CrossRef]

49. Govindan, K.; Bouzon, M. From a Literature Review to a Multi-Perspective Framework for Reverse Logistics Barriers and Drivers. J. Clean. Prod. 2018, 187, 318-337. [CrossRef]

50. Rajeev, A.; Pati, R.K.; Padhi, S.S.; Govindan, K. Evolution of Sustainability in Supply Chain Management: A Literature Review. J. Clean. Prod. 2017, 162, 299-314. [CrossRef]

51. Álvarez-Gil, M.J.; Berrone, P.; Husillos, F.J.; Lado, N. Reverse logistics, stakeholders' influence, organizational slack, and managers' posture. J. Bus. Res. 2007, 60, 463-473. [CrossRef]

52. Baenas, J.M.H.; De Castro, R.; Battistelle, R.A.G.; Gobbo, J.A. A study of reverse logistics flow management in vehicle battery industries in the midwest of the state of São Paulo (Brazil). J. Clean. Prod. 2011, 19, 168-172. [CrossRef]

53. Chang, Q.; Zheng, H. An effective strategy for non-defective reverse logistics. In Proceedings of the 2014 IEEE International Conference on Information and Automation (ICIA), Hailar, China, 28-30 July 2014. [CrossRef]

54. Mollenkopf, D.; Closs, D.J. The hidden value in reverse logistics. Supply Chain Manag. Rev. 2005, 9, 34-43.

55. Chen, D.; Ignatius, J.; Sun, D.; Zhan, S.; Zhou, C.; Marra, M.; Demirbag, M. Reverse Logistics Pricing Strategy for a Green Supply Chain: A View of Customers' Environmental Awareness. Int. J. Prod. Econ. 2019, 217, 197-210. [CrossRef]

56. Ya-Ping, C. Cost and benefit analysis of reverse logistics. In Proceedings of the 2012 Second International Conference on Business Computing and Global Informatization, Washington, DC, USA, 12-14 October 2012. [CrossRef]

57. Doan, L.T.T.; Amer, Y.; Lee, S.-H.; Phuc, P.N.K.; Dat, L.Q. E-Waste Reverse Supply Chain: A Review and Future Perspectives. Appl. Sci. 2019, 9, 5195. [CrossRef]

58. Ostertagová, E. Aplikácia štatistických testov dobrej zhody. Transf. Inovácií. 2012, 23, 72.

59. Pacáková, V.; Labudová, V.; Sipková, L’; Šoltés, E.; Vojtková, M. Štatistické Metódy pre Ekonómov; Iura Edition: Bratislava, Slovakia, 2009; 405p.

60. DB Schenker. Environmental. Available online: https://www.dbschenker.com/sk-en/about/sustainability/environmental (accessed on 20 October 2020).

61. Deutsche Post AG. Environment \& Solutions. Available online: https://www.dpdhl.com/en/responsibility/environment-andsolutions.html (accessed on 22 October 2020).

62. The Green Market Oracle. IKEA's Sustainable Supply Chain Leadership. Available online: http:/ / www.thegreenmarketoracle. com/2018/07/ikeas-sustainable-supply-chain.html (accessed on 25 October 2020).

63. Simões, R.; Carvalho, C.; Félix, R.; Arantes, A. Survey of Reverse Logistics Practices-The Case of Portugal. In Proceedings of the 6th International Conference on Operations Research and Enterprise Systems, Porto, Portugal, 23-25 February 2017. [CrossRef]

64. Deloitte Consulting. The Hidden Value in Reverse Logistics. Point of View. Available online: https://www2.deloitte.com/ content/dam/Deloitte/be/Documents / process-and-operations/BE_POV_Supply-chain-strategy_20140109.pdf (accessed on 29 October 2020).

65. Palanivelu, P.; Dhawan, M. Green Logistics; TATA Consultancy Services Limited (TCS): Mumbai, India, 2010; pp. 1-20.

66. Lisec, A.; Antić, S.; Campuzano-Bolarín, F.; Pejić, V. An Approach to Packaging Waste Reverse Logistics: Case of Slovenia. Transport 2016, 33, 1104-1112. [CrossRef] 
67. Martins, V.W.B.; Anholon, R.; Quelhas, O.L.G.; Leal Filho, W. Sustainable Practices in Logistics Systems: An Overview of Companies in Brazil. Sustainability 2019, 11, 4140. [CrossRef]

68. Vazifehdan, M.N.; Darestani, S.A. Green Logistics Outsourcing Employing Multi Criteria Decision Making and Quality Function Deployment in the Petrochemical Industry. Asian J. Shipp. Logist. 2019, 35, 243-254. [CrossRef] 